\title{
PENGAMBILAN AIR DARI SISTEM ISOPROPIL ALKOHOL - AIR DENGAN DISTILASI ADSORPTIF MENGGUNAKAN ZEOLIT ALAM DAN SILIKA GEL
}

\author{
Silviana*) dan Aprilina Purbasari \\ Jurusan Teknik Kimia Fakultas Teknik UNDIP Semarang \\ Jl. Prof. Soedarto, SH, Tembalang, Semarang 50239, Telp.(024)7460058 \\ ${ }^{*}$ Penulis korespondensi: sheelphi@yahoo.com
}

\begin{abstract}
Abstrak
Isopropil alkohol (IPA) merupakan pelarut umum yang digunakan di industri. Secara ekonomi, dalam penggunaan pelarut perlu diupayakan proses pengambilan kembali pelarut tersebut. Kendala pengambilan kembali pelarut IPA dalam sistem IPA-air adalah sistem tersebut membentuk azeotrop. Untuk itu, penelitian ini mengkaji proses pengambilan air dalam sistem IPA-air melalui proses distilasi adsorptif menggunakan adsorben zeolit alam dan silika gel sebagai adsorbennya. Percobaan dilakukan dengan variabel tetap volume umpan sebesar $200 \mathrm{ml}$, dan variabel berubah jenis adsorben (zeolit alam dan silika gel) dan komposisi umpan IPA (70, 73, 75, 80 \%-b). Proses distilasi adsoprsi dijalankan selama 30 menit sampai keluar produk, selanjutunya pengambilan produk untuk dianalisa tiap 5 menit dengan analisa gravimetri. Hasil penelitian menunjukkan penggunaan adsorben silika gel lebih efektif dan selektif menyerap air daripada zeolit alam. Dan didapat kondisi optimum penggunaan silika gel komposisi umpan adalah 75\% berat IPA dalam larutan hingga kemurnian IPA hingga 91,6\% pada menit ke dua puluh.
\end{abstract}

Kata kunci: distilasi adsorptif, isopropil alkohol, silika gel, zeolit alam

\begin{abstract}
Isopropyl alcohol(IPA) is a common solvent for industry. It is important to reuse solvent but isopropyl alcohol-water system forms azeotrope system. This research is to study water separation in isopropil alcohol-water system by adsorptive distillation. Adsorptive distillation process is conducted on feed $200 \mathrm{ml}$ for 30 minutes. Operating variables are adsorbent type (natural zeolite and silica gel) and IPA feed composition (70, 73, 75, $80 \%$-w). Product is analyzed in each 5 minutes by gravimetry method. The result shows that silica gel adsorbent is more effective and selective than natural zeolite. Optimum condition is obatained on IPA feed composition $75 \%$-w that gives IPA with purity $91,6 \%$ for 20 minutes operation.
\end{abstract}

Key words: adsorptive distillation, isopropyl alcohol, natural zeolite, silica gel

\section{PENDAHULUAN}

Isopropil alkohol merupakan solven yang penggunaanya cukup besar di industri. Diperkirakan 50\% IPA telah diaplikasikan sebagai solven pada tahun 1992. Mengingat harga IPA relatif lebih tinggi dibandingkan pelarut jenis alkohol lain, untuk itu cara yang umum dilakukan adalah dengan merecovery IPA sebagai solven kembali. Proses recovery yang dilakukan adalah proses distilasi biasa. Dalam hal ini, distilasi biasa belum cukup efisien untuk menghasilkan IPA dengan kemurnian tinggi. Ada beberapa metode untuk mengatasi azetrop ini, misalnya dengan extractive distillation. Proses ini efektif untuk meningkatkan kemurnian IPA di atas titik azeotropnya. Tetapi proses ini juga menimbulkan dampak secara ekonomis, yaitu penambahan entrainer dan proses pemisahan kembali. Teknik yang lain dapat pula dijadikan solusi efektif, yaitu adsorptive distillation (Muhammad, 2006). Dengan metode ini, selain kemurnian IPA didapat lebih tinggi, secara ekonomis lebih efisien. Karena proses ini tidak melibatkan entrainer dan penggunaan adsorben lebih efisien karena mudah diregenerasi secara termal. Pemilihan jenis adsorben didasarkan pada jenis zat yang akan diadsorpsi. Karena dalam hal ini yang diadsorpsi adalah air, maka dipilih jenis adsorben yang 
hidrofilik, dan kita akan membandingkan kemampuan adsorpsi dalam sistem IPA-Air antara silika gel dan zeolit alam.

Distilasi adsorptif merupakan metode pemisahan dimana distilasi dan adsorpsi dilakukan secara simultan. Dalam proses ini terdapat dua kolom distilasi dan satu kolom adsorben yang terletak diantara kedua kolom distilasi tersebut. Pada kolom distilasi pertama akan menghasilkan distilat yang berapa dibawah komposisi titik azeotrop. Kemudian distilat akan melewati adsorben. Adsorben akan menyerap salah satu komponen (air) sehingga kemurnian IPA naik dan dapat melewati titik azeotrop. Terakhir di kolom distilasi kedua distilat dimurnikan lagi kadarnya. Perbedaan yang mendasar antara distilasi adsorptif dengan metode lain azeotrop distilasi adalah penambahan komponen tidak dicampurkan bersamaan dengan dengan larutan tetapi pada tempat yang terpisah. Dengan keadaan seperti ini, pemisahan selanjutnya antara komponen tambahan dengan larutan tidak diperlukan.

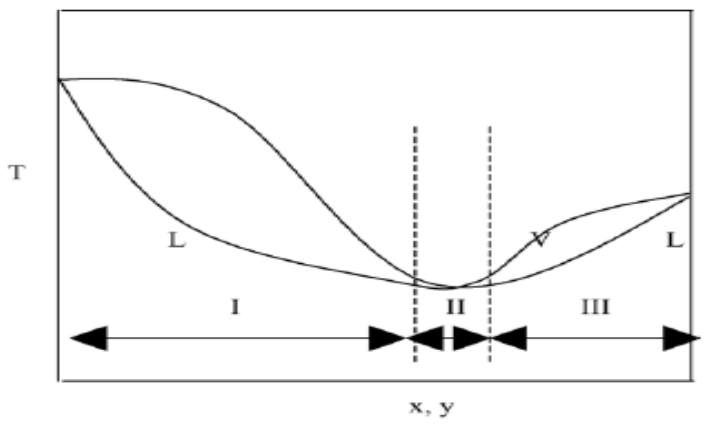

Keterangan :

$$
\begin{array}{ll}
\text { I } & =\text { zona distilasi I } \\
\text { II } & =\text { zona adsorpsi } \\
\text { III } & =\text { zona distilasi II } \\
\mathrm{L} & =\text { fase cair } \\
\mathrm{V} & =\text { fase uap } \\
\mathrm{T} & =\text { suhu }
\end{array}
$$$$
\mathrm{x}, \mathrm{y}=\text { fraksi mol }
$$

Gambar 1. Diagram VLE Isopropyl Alkohol - Air

Distilasi adsorpsi dibagi atas tiga zona yaitu distilasi-adsorpsi-distilasi. Ini dapat dijelaskan pada diagram VLE pada gambar 1 yaitu (I) distilasi dari kadar konsentrasi feed sampai sedikit dibawah titik azeotrop, (II) adsorpsi dari sedikit dibawah hingga sedikit diatas titik azeotrop, (III) distilasi dari sedikit diatas titik azeotrop hingga kadar 100\%. Prinsip dasar dari distilasi adsorptif adalah, karena salah satu komponen diadsorpsi lebih kuat maka komponen yang tidak teradsorpsi akan meningkat komposisi pada fase cairan. Walaupun adsorben memiliki kemampuan menangkap semua komponen yang terdapat dalam campuran, adsorben akan mengadsorpsi dengan proporsi yang berbeda berdasarkan perbedaan polaritas. Tujuan dari penelitian ini adalah menentukan pengaruh waktu terhadap kadar IPA pada berbagai penyerap.

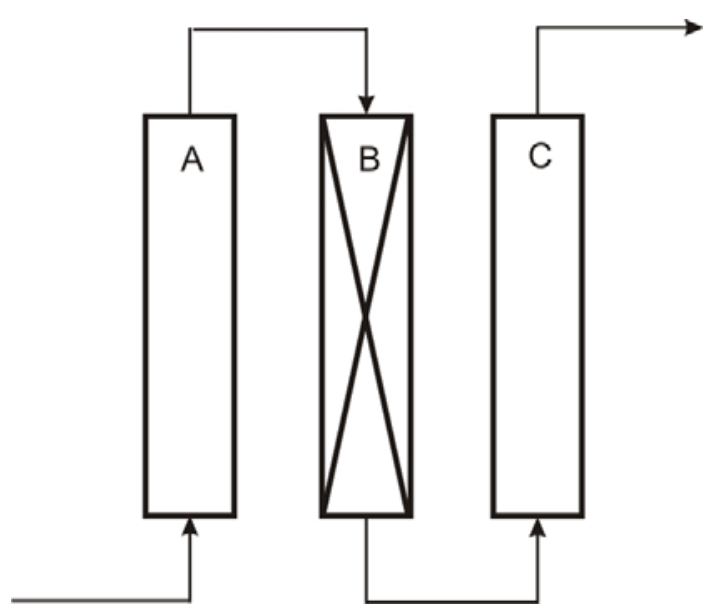

Keterangan :

$\mathrm{A}=$ kolom distilasi I

$\mathrm{B}=$ kolom adsorpsi

$\mathrm{C}=$ kolom distilasi

Gambar 2. Skema proses distilasi

\section{METODE PENELITIAN}

Bahan yang digunakan dalam penelitian ini meliputi IPA, air, zeolit dan silika gel. Peralatan yang digunakan adalah 2 unit kolom distilasi dan 1 unit kolom adsorpsi yang terangkai secara simultan.

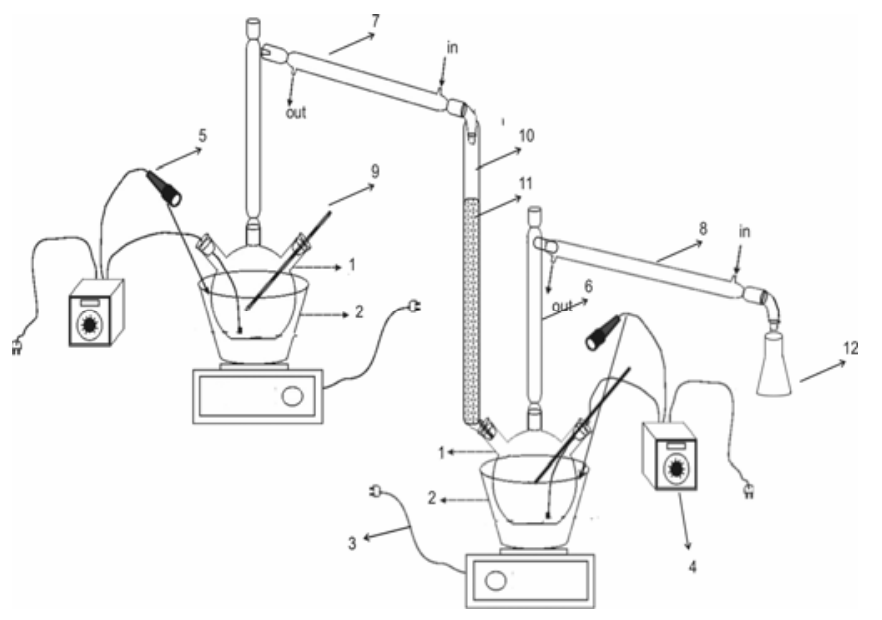

Keterangan :

1. Labu leher tiga

2. Waterbath

3. Kompor listrik

4. Thermocontroler

5. Heater

6. Kolom distilasi

7. Kondensor

8. Pendingin leibig

9. Themrometer

10. Kolom adsorpsi

11. Adsorben

12. Erlenmeyer

Gambar 3. Rangkaian Alat Utama 
Percobaan dilakukan dengan variabel tetap yaitu volume umpan sebesar $200 \mathrm{ml}$ dan variabel berubahnya yaitu penggunaan zeolit dan silika gel sebagai adsorben, dengan komposisi umpan sebesar 70\%, 73\%, 75\%, dan $80 \%$ berat. Aktivasi zeolit dilakukan secara kimia yaitu zeolit dicampur dengan larutan asam $\mathrm{H}_{2} \mathrm{SO}_{4}$, dibiarkan selama kira-kira 2 jam, kemudian dicuci dengan air sampai netral dan selanjutnya dikeringkan. Proses distilasi adsoprsi dijalankan selama 30 menit sampai keluar produk, selanjutnya pengambilan produk untuk dianalisa tiap 5 menit. Analisa menggunakan gravimetri yaitu menimbang berat jenis yang kemudian diplotkan ke kurva standar sehingga terbaca kadar IPA.

\section{HASIL DAN PEMBAHASAN}

Perbandingan berat adsorben zeolit dan silika gel sebelum dan setelah proses tersaji pada tabel 1 .

\section{Pengaruh Zeolit dan Silika Gel dalam Proses} Pengambilan Air dari Sistem IPA-Air

Hasil penelitian pengaruh zeolit dan silika gel dalam proses pengambilan air dari sistem IPA-Air ini tersaji pada gambar 4.

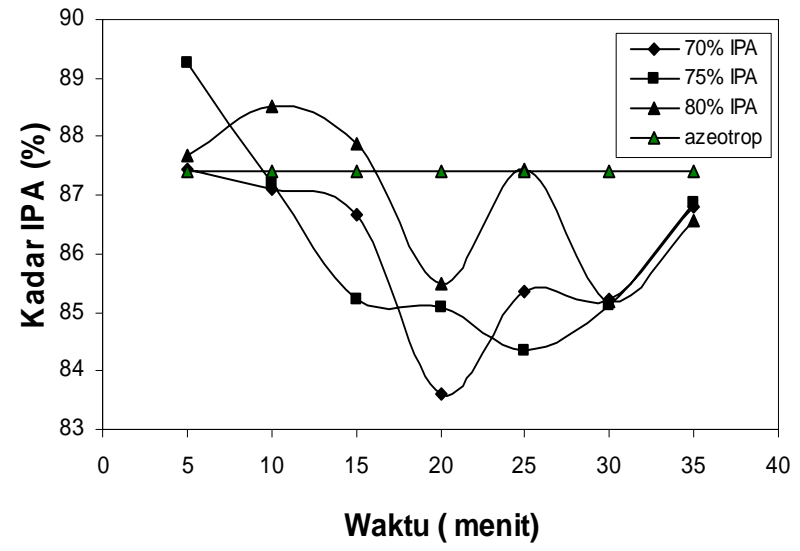

Gambar 4. Kadar IPA (\%) vs waktu (menit) dengan zeolit

Dari gambar 4 dapat dilihat, semakin tinggi komposisi umpan, kadar rata-rata IPA setelah kolom kedua semakin tinggi. Tetapi arah kurva menurun, yang berarti, zeolit tidak efektif berfungsi memisahkan IPA dengan air. Fenomena ini desebabkan karena zeolit mampu menyerap asam organik, sehingga IPA dalam larutan juga diserap (Ulmann, 1986). Zeolit alam yang telah diaktivasi, daya pemucatnya menjadi lebih tinggi karena asam mineral tersebut bereaksi dengan komponen berupa garam Ca dan Mg yang menutupi pori-pori adsorben. Di samping itu asam mineral melarutkan $\mathrm{Al}_{2} \mathrm{O}_{3}$ sehingga dapat menaikkan perbandingan jumlah $\mathrm{SiO}_{2}$ dan $\mathrm{Al}_{2} \mathrm{O}_{3}$ dari (2-3):1 menjadi (5-6):1. Zeolit dengan perbandingan jumlah $\mathrm{SiO}_{2}$ dan $\mathrm{Al}_{2} \mathrm{O}_{3}$ tinggi bersifat hidrofobik dan akan menyerap molekul yang tidak polar (Sutarti, 1994). Dengan melihat tingkat kepolaran air dengan IPA, bahwa IPA lebih tidak polar sehingga IPA dapat diserap zeolit. Hal ini juga dapat dilihat dari berat zeolit setelah proses yang memiliki gradien berat lebih besar daripada gradien berat silika gel. Oleh karena itu, zeolit mudah dalam kondisi jenuh. Hal ini terlihat adanya penurunan kadar IPA terhadap waktu lebih cepat.

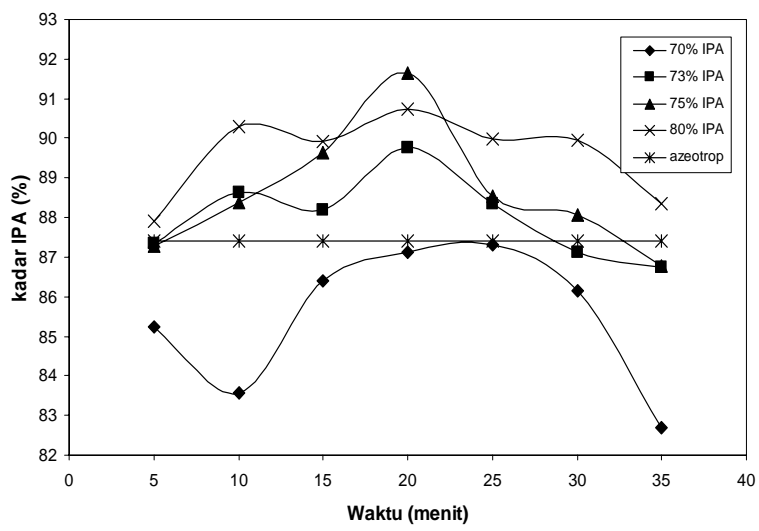

Gambar 5. Kadar IPA (\%) vs waktu (menit) dengan silika gel

Dari gambar 5 dapat dilihat, semakin tinggi komposisi umpan, kadar rata-rata IPA setelah kolom kedua semakin tinggi. Tetapi pada komposisi umpan 75\% hampir semua titik diatas azeotrop, sehingga titik ini merupakan titik optimum komposisi umpan. Bila komposisi umpan dibawah 75\%, maka kemurnian IPA rata-rata belum diatas azeotrop, tetapi apabila komposisi umpan diatas 75\%, maka proses tidak efektif, karena pada kondisi ini secara distilasi biasa dapat dinaikkan kemurniannya. Silika gel lebih efektif karena selektifitas penyerapannya tinggi. Pori silika gel hanya dapat menyerap ukuran molekul air.

Tabel 1. Perbandingan berat adsorben zeolit dan silika gel sebelum dan setelah proses

\begin{tabular}{lccccccccc}
\hline \multirow{2}{*}{ Keadaaan } & \multicolumn{4}{c}{ zeolit } & \multicolumn{4}{c}{ silika gel } \\
\cline { 2 - 9 } & 70\%IPA & 73\%IPA & 75\%IPA & 80\%IPA & 70\%IPA & $73 \%$ IPA & $75 \%$ IPA & 80\%IPA \\
\hline awal & 116 & 116 & 116 & 116 & 117 & 117 & 117 & 117 \\
setelah proses & 136,6 & 139,09 & 137,52 & 136,1 & 129,8 & 130 & 131 & 129 \\
pemanasan $<100^{\circ} \mathrm{C}$ & 129,2 & 132,3 & 130,8 & 131,8 & 129,6 & 129,9 & 131 & 128,8 \\
pemanasan $>100^{\circ} \mathrm{C}$ & 116 & 116 & 116 & 116 & 117 & 117 & 117 & 117 \\
\hline
\end{tabular}




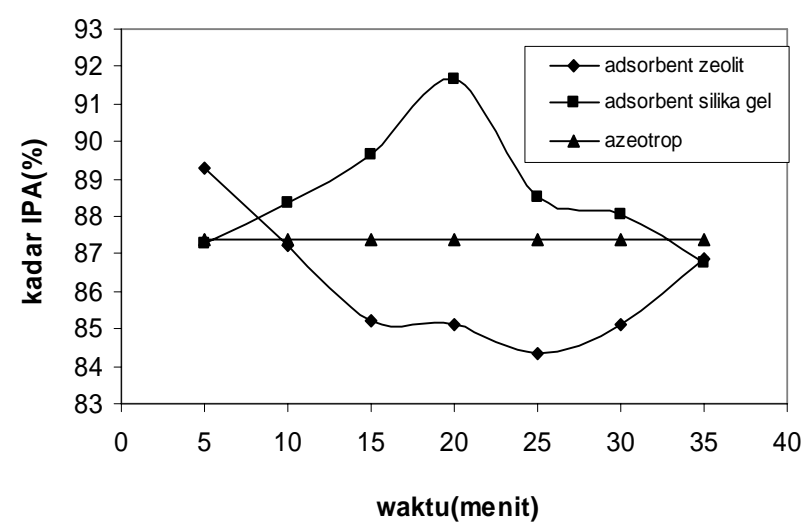

Gambar 6. Kadar IPA (\%) vs waktu (menit) pada umpan $75 \%$ IPA

Dari gambar 6 dapat dilihat, pada komposisi umpan yang sama, silika gel lebih efektif dibanding dengan zeolit. Hal ini dikarenakan, silika gel lebih selektif menyerap air daripada zeolit yang selain menyerap air juga menyerap IPA. Karena ukuran pori zeolit yang besar dapat menyerap IPA juga. Terlihat dengan silika gel, didapatkan komposisi IPA tertinggi dicapai hingga 91,6\%. Proses distilasi adsorptif akan lebih efektif jika menggunakan adsorben silika gel. Hal ini terlihat dari kadar rata-rata IPA setelah keluar kolom kedua proses distilasi adsorptif menggunakan adsorben silika gel lebih besar daripada menggunakan zeolit alam. Ini dikarenakan sifat adsorpsi silika gel yang lebih selektif menyerap air daripada zeolit alam. Secara ukuran molekul juga dapat dijelaskan bahwa dengan pori yang besar yaitu 30-100 nm, (Sutarti, 1994), zeolit mampu menyerap molekul IPA yang ukurannya $6,2^{\circ} \mathrm{A}$, sedangkan silika gel yang ukuran porinya sebesar $2-5^{0} \mathrm{~A}$ (Perry, 1988) hanya mampu menyerap molekul air yang memiliki diameter $2,75 \mathrm{~A}^{\circ}$.

\section{Kondisi Optimum Komposisi Umpan dengan Adsorben Zeolit Alam dan Silika Gel}

Dari gambar 4 tidak dapat dilihat konsisi optimum komposisi umpan, karena pada semua variasi komposisi umpan menunjukkan penurunan kadar IPA produk sebagai fungsi waktu. Dari gambar 4 hanya dapat dilihat bahwa waktu optimum adalah 5 menit dan kondisi optimum komposisi umpan tidak dapat ditentukan untuk mendapat komposisi produk di atas azeotrop. Hal ini dikarenakan zeolit, selain menyerap IPA juga menyerap air. Dapat dilihat dari tabel 5, yang menunjukkan pemanasan di bawah $100^{\circ} \mathrm{C}$ terjadi penurunan berat yang berarti zeolit juga menyerap IPA yang memiliki titik didih $82,3^{\circ} \mathrm{C}$. Fenomena ini disebabkan karena sifat zeolit yang mampu menyerap asam organik dan ditinjau dari ukuran molekul, zeolit yang porinya berukuran 30 - $100 \mathrm{~nm}$, (Sutarti, 1994), mampu menyerap IPA yang molekunya berukuran $6,2^{0} \mathrm{~A}$

Dari gambar 5 dapat dilihat bahwa kondisi optimum dicapai pada menit ke 20. Dan komposisi umpan optimum adalah 75\%. Dari gambar dapat juga terlihat pola grafik komposisi produk terhadap waktu, yang secara umum membentuk kurva parabola atas. Hal ini disebabkan tingkat kejenuhan silika gel yang berubah. Dari t ke nol sampai t ke 20 cenderung mengalami kenaikan, hal ini disebabkan kemampuan silika gel menyerap air masih baik. Sedangkan setelah t ke 20, silika gel mulai jenuh dan menyebabkan kemampuan menyerap air semakin menurun. Pada tabel 1 memperlihatkan tidak adanya penurunan berat yang signifikan selama pemanasan dibawah $100{ }^{\circ} \mathrm{C}$. Ini menunjukkan bahwa silika gel lebih selektif dalam menyerap molekul air. Dan ditinjau dari ukuran molekul, silika gel hanya dapat menyerap air yang memiliki diameter molekul $2,75^{\circ} \mathrm{A}$ dengan ukuran pori silika gel $2-5^{0} \mathrm{~A}$ (Perry, 1988)

Dapat dilihat bahwa kondisi optimum pada penggunaan adsorben zeolit adalah pada t ke 5 tetapi komposisi optimum untuk mendapat produk yang diinginkan, yaitu di atas azeotrop, tidak dapat ditentukan. Sedangkan kondisi optimum pada penggunaan adsorben silika gel adalah pada t ke 20 dan komposisi optimum untuk mendapat produk yang diinginkan adalah $75 \%$ kadar IPA dalam larutan. Hal ini disebabkan zeolit tidak selektif dalam menyerap air, sedangkan silika gel lebih selektif menyerap air.

\section{KESIMPULAN}

Dari hasil penelitian dapat disimpulkan bahwa hasil optimum didapat pada menit ke 20 dengan menggunakan adsorben silika gel pada komposisi umpan $75 \%$ yang menghasilkan produk IPA dengan kemurnian 91,6\%.

\section{UCAPAN TERIMA KASIH}

Ucapan terima kasih disampaikan kepada Mona Silvia dan Ragil Darmawan yang telah membantu pelaksanaan penelitian ini.

\section{DAFTAR PUSTAKA}

Barbara, E., and Stephen, H., "Ullmann's Encyclopedia of Industrial Chemistry" .

Muhammad, M, Setyawan, W.B, and Sulistyo, H., (2006), “A Preeliminery study: Distillation of Isopropanol - Water Mixture Using Fixed Adsorptive Distillation Method", Chemical Engineering Departement of Muhammadiyah University of Surakarta(UMS) and UGM, Jurnal Separation and Purification Technology., 48, pp. 85-92.

Perry, R., and Green, D., (1988), "Perry Chemical Engineering Hand Book”, Sixth edition, Japan : Mc.Graw Hill International edition.

Sutarti, M, dan Rachmawati, M., (1994), “Zeolit Tinjauan Literatur", Pusat Dokumentasi dan Informasi Ilmiah, Lembaga Ilmu Pengetahuan Indonesia. Jakarta 